\title{
ISLAMIC BANKING SYSTEM IN THE SULTANATE OF OMAN FROM THE PERSPECTIVE OF BANKING OFFICERS EMPLOYEES AND CUSTOMERS
}

\author{
Sultan Khamis Said Al Bulushi \\ Head of Central Operations \\ Ahlibank, Muscat, Sultanate of Oman \\ E-mail: sks2010sultan@gmail.com \\ https://orcid.org/0000-0002-8991-0021
}

Received: September 03, 2021 Accepted: November 09, 2021 Online Published: December 08, 2021

DOI: 10.46281/ijibfr.v8i1.1479

URL: https://doi.org/10.46281/ijibfr.v8i1.1479

\begin{abstract}
This research aims to determine the viability for the operation of Islamic banks within the Omani banking system. By looking into various opportunities for Islamic banking in Oman and given the unique rules on transactions (fiqh muamalat) of Islamic banking based on the Shariah precepts or the so-called Islamic law. As the establishment of small and medium enterprises (SMEs) is rapidly growing in Oman, many SMEs can draw support from Islamic banks. The study used a mixed method approach to answer the research questions. Do the participants patronize Islamic banking over conventional banking?. The study compared both conventional and Islamic Banking. The population of the study represented bank officers, bank employees and customers. The sample of the study $(n=100)$ participated in the survey. Another selected sample participated in interviews. Findings revealed different views over Islamic banking. Islamic banking is careful to provide products and services. Also, they are found to be capable of offering products and processes that answers the need of certain aspects with a risk management framework that is distinct from what normal banking provides. The study findings support the need for Islamic banking systems as it would be easier to spread Islamic banking and financing.
\end{abstract}

Keywords: Islamic Banking, Conventional Banking, Financial Contracts, Banking System, Oman.

JEL Classification Codes: E5, E58, G2, G21, E4, E42.

\section{INTRODUCTION}

For many years, the basic principles of economics and society have been challenged by the Muslim faith especially capitalism, where the Muslim faith tries to expose the different weaknesses of capitalist societies. Since their liberation, Muslims have carried on their faith through various undertakings for which they have become successful participants of societies. From their early growth during the 1970s, Islamic banks (IBs) became a great medium for promoting Muslim faith 
and ideology as in seeped into and integrated itself with various capitalistic economies around the world, leveraging its presence to as much as 50 countries and with their number still increasing today (Hanif, 2011).

The fast-rising Muslim community worldwide has so far increased to more than $25 \%$ of the world population together with the world's dependency on oil and the high possibilities of investments the territorial boundaries of Gulf regions, has made Muslim faith and Sharia concept of justice and all its other principles spread faster around the world. The gulf regions GCC countries experienced serious change and asking for more liberation and diversification as well (Rettab, Kashani, Obay, \& Rao, 2010; Muscat Daily Staff Writer, 2013).

The significant components of Sharia include the prohibition of charging Riba, or interest that comes from loan money (Siddiqi, 2004; Kpodar \& Imam, 2010), and application of Gharar that comes from contractual ambiguity especially in onerous contracts. The extent of these prohibitions includes avoidance of establishing businesses that is involved in selling forbidden goods and services such as alcohol and gambling.

Many economies worldwide have been criticizing how Islamic banks conduct their business where its basic roots are from the Islamic law. With a population dominated by Muslims, Oman welcomes the entry of Islamic banks within its financial and banking system. Notwithstanding the fact that the Muslim faith prohibits the charging of Riba or interest, a distinctive and unique feature of Islamic banking.

This study looks into the different products and services offered by Islamic banks in such manner where they can be suitable to the economic needs and conditions of the Sultanate, notwithstanding traditions and culture, to which Omanis closely adhere to. It encompasses and examines in close scrutiny various contracts within the Islamic banking system that befits the aforementioned economic needs, conditions and traditions of the Sultanate of Oman.

These contracts may include transactional contracts, financing contracts, intermediary contracts and social welfare contracts, where in one way or another could be advantageous to Omanis and make the existence of Islamic Banking more feasible, and therefore profitable within the Sultanate, while performing its basic function as an able partner for the continuing development and growth of Oman.

The opportunities for Islamic banking in Oman shall be identified through an in-depth understanding with the aim of gaining better appreciation of the concept despite its contradictions against the capitalist perspective of charging Riba or interest in the paper.

Contrary to the usual and conventional practices, Islamic banking, which operates under the Sharia law prohibits the charging of interest on loans while encouraging investments through the sharing of profits as well as losses between the bank and its clientele. Under this premise, Islamic banks that operate and those intending to operate in Oman appears to face more risks in the absence of a more predictable fixed returns unless it is directly tied up to the business operations of the customer.

Since this study was conducted in 2010, various and new developments have been in the concept of Islamic Banking in terms of Islamic principles and customers perceptions in the Sultanate of Oman (Belwal \& Al Maqbali, 2019). The recent studies conducted shifted their attention to future of Islamic banking, opportunities of Islamic Banking, issues and challenges that faces Islamic finances in Oman (Mubeen, Kulkarni, \& Al Hussaini, 2014; Magd, \& McCoy, 2014; Salim \& Al Ani, 2015). 
By looking into the concept of Islamic banking, the general business condition in Oman, the product and services it offers, as well as the corresponding risks involved in establishing relationships with Islamic banks, this paper investigates on the opportunities for Islamic Banking in Oman. With utmost diligence, this research investigates any viable possibilities for the growth of Sharia banking in Oman through an assessment of its concepts, the business sector, as well as the financial and banking system of Oman.

The principal purpose of conducting this research is to identify the opportunities for Islamic banking in Oman. Personal interest and desire to learn more on varied banking concepts is one of the main reasons that this research is undertaken.

The research paper aimed to answer the following research questions:

(1) What is the general concept of Islamic banking and how does it differ with the conventional way of banking?

(2) What is the general framework of the banking system of Oman?

(3) As its growth and latitude increases, would small and medium-sized enterprises (SMEs), as well as individuals do they prefer to patronize Islamic banking over conventional banking?

\section{The Islamic Banking Concept}

The Islamic banking concept is a banking concept that excludes the charging of interest to its customers. Based on the principles of Mudaraba and Wakala, Islamic banks accepts demand deposits and makes them interest free loans together with the bearing of profits and loss as it acts as a partner to its clients (Shafique et al., 2012; Al Bahar, 1999).

An Islamic bank is a banking institution that organizes and utilizes its financial resources and allocates to various investments without fixing any interest chargeable to its clients. Islamic banks perform banking activities that are socially and financially aligned with the principles brought forth by the Sharia law (Al Baraka Banking Group, 2013).

Islamic banks carries unique features compared to conventional banks; i.e., they provide an exclusion of the use of interest-based debt transactions but rather it provides the requirement that financial transactions must be in accordance real economic activity" and not tantamount to pure transactions. It also has the prohibition on any exploitative acts, such as the charging of interest or any onerous transaction unfavorable to society (Loghod, 2010).

Generally, the creation of Islamic banks are not entirely designed for profit, as they proscribe the charging of interests. There becomes contradictory and distinct when compared with conventional banking in terms of how Islamic banks could thrive under such conditions of disallowing the charging of interest, the same that conventional and traditional banking does. To the contrary, the International Monetary Fund issues a declaration that in terms of performance, Islamic banks do better than conventional or traditional banks (Shafique et al., 2012). This statement is yet to be proven especially during an economic crisis where banks have to stay liquid as possible, and without the regular charging of interest and their sharing of the burden of losses from business ventures, Islamic banks may suffer more than conventional banks.

On the other hand, some businesses like SMEs would turn to Islamic banks to provide them with the support they need to further or simply just to maintain their businesses as Islamic banks partakes of the gains and losses in their business investments. 
What makes Islamic banking unique is the principles it carries that are founded in the Islam religion. Islamic banking differs from conventional banking along four principles that covers the prohibition of the charging interest, ethical standards in the conduct of the business, social and moral values, and the liability and business risks involved. Where Islamic banking focus on investment, conventional banking focus on lending, where interest can be earned to form profits. Within the precepts of Islamic banking, it is the religious duty of Muslims to invest only in what is good and wholesome. It puts more emphasis on the ethical standards that tries to avoid investments in products and services that could create a negative impact on individuals, society, and the environment itself. Thus, prior to getting investing in any business, Muslims see to it that through their adherence with Sharia principles, they only invest on what is good. In like manner, they are also loyal to the principle of getting involved only in businesses that could provide special services to those who are in need (Al Baraka Banking Group, 2013).

The principle puts emphasis on liability and business risks that are not only share by one party engaged in a contract or transaction, and dislike onerous agreements that favors only one party of the contract (Hanif, 2011). This is known as the concept of Mudharabah or profit sharing, whereby the investor supplies the funds and gets the profits agreed upon in two ways; between the bank as the entrepreneur and the investor. Alternatively, it can be done the other way around, where the contract is between the bank as the capital provider and the entrepreneur or the business, with the losses borne by the capital provider.

Research shows that since 2008, the capitalist banking system, which offers the usual or conventional, banking products and services; has suffered most from the world financial crisis when compared to the business performance of Islamic banks that managed to survive the global economic crisis. Instead of succumbing to the bad repercussions of the dire economic conditions, Islamic banking has steadily managed to survive the disaster. The crash of the international capital markets has been attributed to the speculative transition and the sloppy lending system of these markets, as well as the banking conditions during the financial crisis (Dewi \& Ferdian, 2009 ). This can be true as banks should be a country's support to finance projects that leads to innovation that would create a competitive advantage for the country.

It was reported by Fitch Ratings that Islamic banks that found in the Sultanate of Oman are predicted to struggle first during worst economic conditions, in order to compete favourably with established names in conventional banking like the Bank of Muscat and HSBC Bank Oman. Islamic banks offer Shariah services in compliance with the religious tenets of Islam as well as to the demands of the Omani banking market. Conventional banks, however, have the edge over Islamic banks because of their established networks, adeptness of service and cost-efficiency savings (AMEInfo.com, 2012). Some researches have also claimed that Islamic banks have greater tenacity and capability to mitigate risks than conventional banks during a financial crisis.

There are also other findings that have speculated on how Islamic banks are able to survive any financial crisis in as much as it can help the economy survive the same. The present and the past both have merits in evaluating the opportunites for Islamic Banking in Oman, and will be discussed in this paper.

\section{Financial Contracts Under Islamic Banking}

Islamic banks are involved with specific contracts based along the four Sharia principles aforementioned.The first one deals with the sale, exchange and the trade of certain goods and services. This is called a transactional contract. 
The second type covers various ways of extending credit to facilitate financing and transactional contracts between investors and entrepreneurs for capital formation and resource recruitment. The second type consists of intermediatry services whereby agents are utilized to provide fee-based services for economic activities. Lastly, it is also involves in promoting the welfare of those who are less advantaged in life through social welfare contracts that are made between society and indviduals living in it (Usmani, 2002).

Transactional contracts utilizes two types of exchanges; from the sale of an asset to the sale of rights to be able to use an asset. As exchange contracts can vary, Islamic banks utilizes the Bay' al-Muajjil, which is a contract that allows the sale of a product on the basis of deferred payment in installments or in lump sum payment. Here the two parties involved in the contract are the sellers and buyers who agree about the price of the product time of sale without any conditions on any charges for making deferred payments.

Another contract under Islamic principles is the Bay'al-Salam, which is a contract between two parties where buyers agree to pay the sellers full negotiated price for a specific product that the seller promise to deliver in a specified time in the future.

Lease agreements are known as Ijarah, which is more of a sale of a usufruct rather than a sale of a tangible asset. A contract between manufacturer and buyer for manufacturing or construction of an asset with specific features and price is called Itisna, which takes on when the manufacturer takes on the responsibility to manufacture the buyer's asset (Kahf et al., 1998).

Under the concept of Islamic banking, significant and often used contracts include the Murabaha, Mudaraba and Musharak.

The Murabaha is a contract between the bank and the customer for the sale of goods at an agreed price which includes purchase price or lump sum, where the bank first have to purchase the goods for the customer and sell it at a profit earned over a period of time. Here the bank provides the capital while the other party provides the expertise with an agreed profit. In case of losses, both parties share the burden in terms of the time and the capital invested in the project (Lewis \& Algaoud, 2001).

The Musharaka, on the other hand, is a partnership between two parties who both provide capital towards the financing of new or established projects. Profits under this agreement are shared on a pre-agreed ratio, allowing managerial skills to be remunerated, and losses are shared based on the percentage of equity participation. The very concept of Musharaka means sharing. Either party can commit himself in the management of the project (Siddiqui, 1987). Profits made may not be in the same proportion as the amount of investment but losses incurred will be shared based on the ratio of funds invested by each partner (Kahf et al., 1998). Ijarah Thumma Bai' or the "Hire purchase" concept, which is used in financing consume goods often with financing of motor vehicles. Two separate contracts are involved in Ijarah; first Ijarah contract (leasing/renting) and the other is the "Bai" contract which is one for the purchase of a good or item. (Kahf et al., 1998). Conventional banks however, are capable of providing special products under specific 'windows' or subsidiaries. For example, the Honking and Shanghai Banking Corporation of HSBC have its window branch that operates and performs accounting operations that are separate from its conventional banking operations. Wakela (Agency) is a contract between a principal and an agent for a specific service or task for a fee. Qard (Interest-free loan), which is a loan for a fixed period based only on goodwill with the borrower only required to pay the principal amount without any interest. The borrower may also wish to pay an extra amount to thank the lender (Kahf et al., 1998). Hibah (Gift) is a payment made willingly in return for a benefit received. 


\section{The Difference between Islamic Banking and Conventional Banking}

Islamic banking main purpose is to remove interest in all banking activities and out Halaal or those transactions, which are only permitted transaction. The bank shares the risk among investors, and this is its most significant feature as its focus lies on the fairness and freedom as a centrally controlled system. Islamic banks are banking instructions that conducts banking activities primary involving the borrowing and lending of money without interest. Fund mobilization is based on Mudarbah or Wakalah, and may also accept demand deposits as interest-free loans. (Al-Jarhi \& Iqbal, 2001) An Islamic bank operates as an investment manager of funds based on the principles of Shariah, and distributes them based on profit and loss system.

With two banks streams operating in Oman, the idea would require more scrutiny to analyze various opportunities for Islamic banks in Oman. Using as a basis the quality of service that they offer, and how knowledgeable target customers are on its potential service and their performance in some other parts of the world where it operates focusing on the just and equitable distribution of resources rather than on interest as what conventional banks do (Siddiqui, 1987).

Islamic banking based on the precepts of Islam is open to innovative products and practices using the Ijtihad and the holy Quran and Sunnah as the source of all their actions. Islamic banks functions in such a way as an investment manager that is, investing depositors fund in the general investment fund and accept demand deposits free of interest, which is contrary to how conventional banks earn money. Conventional banks on the other hand, have predetermined interest rates (Hasan \& Dridi, 2010), and only aim for profit maximization at the expense of its stakeholders and society, as well.

The Main Differences between Islamic Banks and Conventional Banks include the followings: 1. Principles: Islamic banks follow the principles of Shariah, which has its source from Allah Almighty as an imperative in the conduct of its business.

Conventional banks have principles, which are created by human beings, which more often than not are subject to changes.

2. Source of Earnings: The source of earnings for Islamic banks comes from profit, service charges and the consultancy fees for their services. This can be variable, especially at times when losses occur as they are borne by the bank.

Conventional banks rely on the interest they earn from loans apart from service charges and fees for their services. Interest is predetermined and fixed.

3. Risk Sharing: Risk is shared among the borrower, or the lender, and the bank. The risk is shifted but profit obtained is still subject to the principles of Shariah. Conventional banks carry no restriction even at the cost of stakeholders.

4. Objectives: Islamic banks are Mudaribs or Wakalahs; that is they work as a trading concern to facilitate investments in order to generate income. As an intermediary, it facilitates trade transactions before it can get its share from what the business earns. Conventional banks on the other hand, keep profit maximization as its main goal and nothing else.

5. Earnings: The incomes derive by Islamic banks is variable and depends upon the conditions of the existing business environment. The income earned by conventional banks remains constant as the interest it charges is already fixed or predetermine regardless of the volume of profit that comes into its coffers.

Rosmanidar, Al Hadi, and Ahsan (2021) conducted a meta-analysis of more than 100 research article tracking the development of Islamic Banking (IB) throughout the history since its revolution of earliest publication in 2003 as the first article was published. Although research in Islamic Banking started to increase since 2010 and reached 13 articles in 2018, the number is still 
not sufficient among other scholarly papers. The study revealed that in the time of crisis, Islamic Banking research indicated that operation of Islamic Banking is different from conventional banking. In addition, despite insufficient research in Islamic Banking, recent research revealed better performance of Islamic banking in the times of crisis and were more stable. From metaanalysis findings, Rosmanidar, Al Hadi, and Ahsan (2021) classified the aspects to measurement of Islamic banking on three including financial, social and contribution to stability of the financial system (Hasan \& Dridi, 2010). Looking back to studies conducted in the field they were mostly focusing on $\mathrm{GCC}$ and $\mathrm{Al}$ shariah banking.

In terms of Islamic Banks (IBs) trends, Rizwan (2021) investigated the developments of Islamic banks versus conventional banks in Pakistan using CAMEL analysis. The findings revealed increased trends in Return on Asset of Islamic Banks during 2015 and 2018, and performed better during the same period than the conventional banks. Interestingly, IBs showed significant growth between 2015 and 2019 in terms of its Return to Equity, Return to Asset and Capital Adequacy ratio over the five-year time. The comparison revealed that in terms of Asset Quality and Earnings IBs still performed better than CBs. In contrast, CBs performed better in terms of management efficiency, capital adequacy and liquidity.

\section{The Banking System of Oman}

Establishing business relationships in Oman is basically built on good relations between both parties. Omanis do business with their business partners in a more personal level than normal business relationships are, that is, they try to get to know their business partners first and every transaction is built based on credibility and trust.

At the core of all banking activities of the Sultanate of Oman is the Central Bank. Below it, are various commercial and specialized banks that recognize the important role of the banking sector plays in maintaining the financial and economic equilibrium and stability of the Sultanate. The Central Bank of Oman acts as an overseer of all banking activities and operations of all banks by regulating all banking activities in accordance with the government mandates of the Sultanate.

The Central Banks also sees to it that they provide the most efficient services that would help the Sultanate achieve regional and international financial needs and developments, including the liberalization of financial services within the regulated framework of the World Trade Organization (WTO. The Central Bank of Oman also holds the responsibility of keeping stable and maintaining the monetary currency of the country, which is the Omani Rial, just within a deregulated and open financial system based on the implementing guidelines set by the World Trade Organization. The College of Banking and Financial Studies plays a significant role in manpower building by preparing Omanis to pursue banking careers.

\section{Specialist Banks}

The creation of specialist banks in Oman was made in order to support the national development efforts of the Government, and to perform specific functions in the field of housing, industry, agriculture and fisheries in Oman. These are the Oman Housing Bank (OHB), the Oman Development Bank (ODB), and the Alliance Housing Bank (AHB). The Oman Housing Bank (OHB) provides affordable housing loans for Omani nationals. With a capital of RO30 million the bank has widen the scope of its operations and charges only a limited service fee loans subsidized by the Government. The bank also grants non-subsidized loans and additional facilities. Through the Royal Decree No. 18/2006 that was issued in March 11, 2006, the Oman Development Bank was established in collaboration with the Oman Bank for Agriculture and Fisheries. 
The ODB was established by the Government to support small projects through a social perspective. The Ministry of Commerce and Industry or some other financial institutions is the one responsible to finance projects that need an excess of funds other than the maximum set for small projects. Projects funded by the ODB are exempted from the payment of taxes and are subsidized by the government in terms of the interests that are supposed to be payable on soft loans for the private sector, either for the medium or long-term basis. Further, the ODB also provides technical and advisory services to companies while at the same time acts as an export credit guarantee agent that also facilitates the distribution of funds coming from the Fisheries Research Fund.

Among these specialized banks, it is only the Alliance Housing Bank (AHB) that is privately owned yet still works in collaboration with the government to support its affordable housing programs. The AHB is also designed to take care of the building construction sector of Oman. The bank was established and incorporated in 1997 and is the Gulf Cooperation Council's first private sector housing bank.

Regarding the securities market of Oman, it was created by virtue of the Royal Decrees Nos. 80/98 and 82/98 where it has three separate bodies in the Sultanate to take care of the country's capital market activities; CMA, MSM and the Muscat Depository and Securities Registration Co. (MDSRC). The Capital Market Authority or CMA, by virtue of the Royal Decree No. 53/88, issued on 21 June 1988 was created and functions as a regulatory body of the government. The CMA has the responsibility of "organizing and overseeing the issue and trading of securities in the Sultanate". Oman also operates a government-owned stock exchange named Muscat Securities Market (MSM) where all listed securities are traded. The MSM enjoys its autonomous power to act independently yet still subject to Government supervision. The stock exchange was created in accordance with the Royal Decree 53/88 that was issued on 21 June 1988. Currently, MSM is connected to the stock exchanges of Abu Dhabi, Dubai, Doha, Manama, Cairo and Alexandria.

Lastly Oman has the Capital Market Authority (CMA), which is a regulatory and licensing body it is responsible for monitoring the issue and trading of securities and overseeing MSM's operations while also developing the Omani capital market sector's legislative and regulatory structure. Muscat Depository and Securities Registration Company Co. (MDSR) were created by virtue of the Royal Decree 82/98 dated November 25th, 1998. The royal degree provided for the establishment of a closed joint stock company as the lone securities provider in the Sultanate, with the provision of such services, such as the registration and transfer of ownership of securities and safekeeping of ownership documents (depository). This company is linked through an electronic system to the MSM for easy data transfer.

\section{METHOD}

In terms of study methodology and resource collectons, hard copies of books and other relevant materials are used in the study together with Internet links and databases to a derivation of the theory within an analytical framework of raw data. As the field of banking covers a broad area of investigation, the inductive approach provides a logical structure of presenting information and in incorporating it with several new dimensions in banking within the context of Islamic banking. Field work or survey was also another method of collecting data for this research. As a secondary source of data, it is perceived to provide useful information and understanding of the problem statement, its various lines of inquiry, and in positing different alternatives through a quantitative analysis of information drawn from the survey. In using secondary sources, utmost care is exercise 
in choosing appropriate information, with allowances for possible inaccuries (Miles \& Huberman, 1994).

\section{Sample}

The respondents who were enjoined to participate in the survey were chosen randomly and consisted of customers, bank officers, and bank employees.

The entire sample $(n=100)$ are presented in the table that follows this descriptions. The age range of respondents are from 40 to 60 years as they are believed to be more equipped with better knowledge on the concept of Islamic Banking, if not have gained considerable experience in the area of banking practice. Age mean for the sample is 52.2 with an SD of 5.6 years.

Table 1. Summary of Participants

\begin{tabular}{|l|l|}
\hline Participants & Number \\
\hline Customers & 40 \\
\hline Bank Officers & 25 \\
\hline Bank Employees & 35 \\
\hline
\end{tabular}

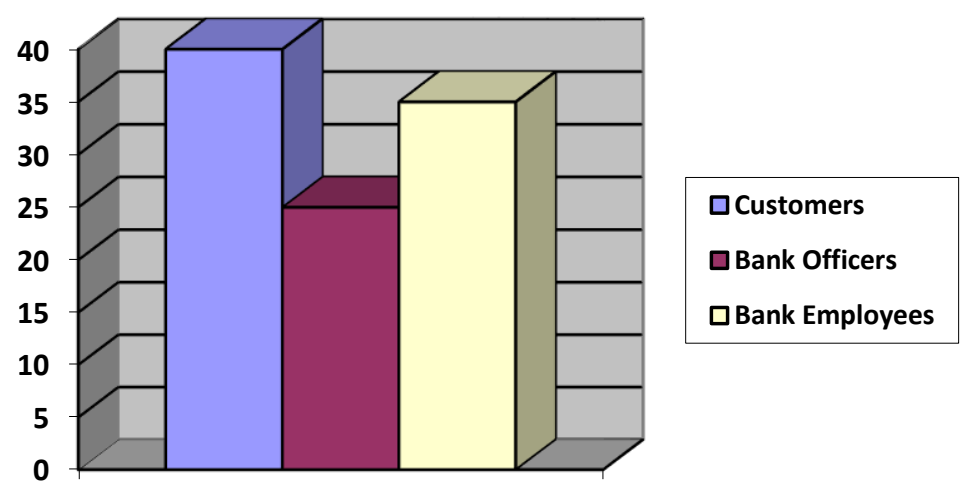

The table and graphical illustration shown above indicates that participants for the survey was made up of a majority of bank customers, followed by bank employees, and lastly by bank officers/managers.

Table 2. Descriptive Sample Characteristics

\begin{tabular}{|l|l|l|}
\hline Gender & Frequency & $\%$ \\
\hline Male & 65 & 65 \\
\hline Female & 35 & 35 \\
\hline
\end{tabular}




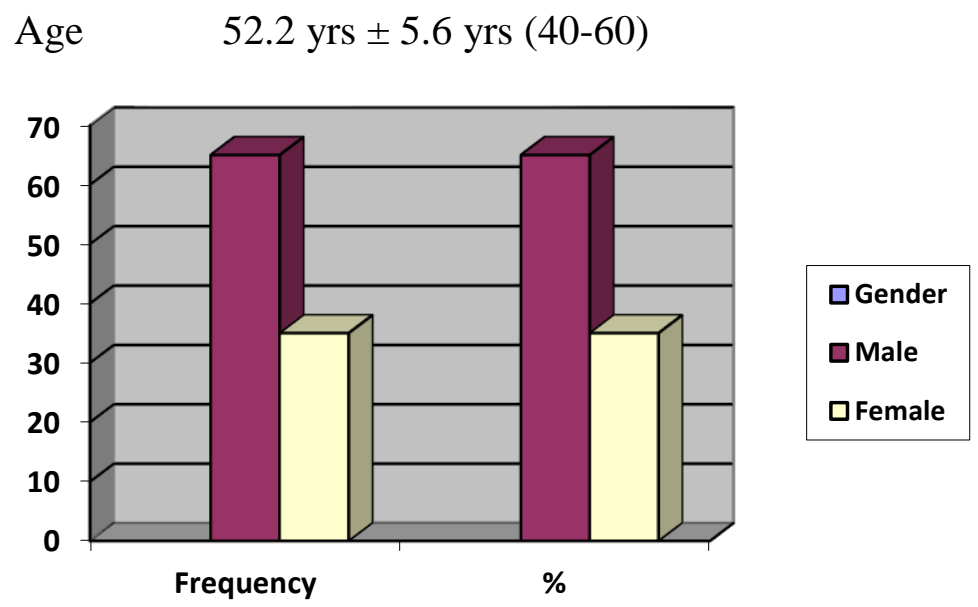

\section{RESULTS}

Since research questions one and two required literature findings to understand the system of banking in Oman and refer to documents, the answers of questions one and two were thoroughly described in literature review sections as well as a combination of survey and interviews. The third question which is : (3) As its growth and latitude increases, would small and medium-sized enterprises (SMEs), as well as individuals do they prefer to patronize Islamic banking over conventional banking?, was answered through participants response to the survey.

Table 3. Survey items to respondents and frequency of agreements

\begin{tabular}{|l|l|l|l|}
\hline Items & Yes & No & Not sure \\
\hline $\begin{array}{c}\text { Will you prefer an Islamic Bank over } \\
\text { traditional banking? }\end{array}$ & 46 & 22 & 32 \\
\hline $\begin{array}{c}\text { Do you think Islamic banks can provide better } \\
\text { products and services offers to } \\
\text { SMEs in Oman? }\end{array}$ & 44 & 19 & 37 \\
\hline
\end{tabular}

Based on the above table, the highest percentage of responses among the participants was "Yes". In contrast, the lowest percentage was the answer "No". This indicates that there is a willingness and openness on the part of participants to patronize Islamic banking within their own level of understanding of its concepts. Those who may have answered "No" (21\%) can be considered as those who have familiarity with Islamic banking but still are not ready to fully imbibe Sharia compliant financial institutions and integrate them with their business activities.

In the fourth question of the survey, results were almost the same with the previous one only then that those who answered in the affirmative ("Yes") was only a percentage lower at $46 \%$, with those who answered "No" is percentage higher (22). Those "Not Sure" (32) remained the same as in the preceding question.

The second question also reflects how Islamic banking and its role as a business and economic partner could enable SMEs to grow and develop wherein such funds can be used as a hedge where Islamic financing shares the risks with their borrowers. Thus, a high percentage indicates a need for Islamic financing activities in Oman. Further, there is also a higher percentage to the "Yes" (44\%) answer than the two other choices. As the establishment of small and medium 
enterprises (SMEs) is rapidly growing in Oman, many of these SMEs can draw support from Islamic banks that could become another partner of progress for the Government.

\section{Interviews}

The interviews with the participants included questions of how they see Islamic banking and traditional bankings. The question: Do you think Islamic banking will surpass the merits of traditional banking?

Bank employees from conventional banks are wary when asked about this question. Looking at their facial expressions and the way the state their answers, leads to a conclusion that they do not want to commit themselves to anything good about Islamic banking. This is understandable in as much as, to what they know about Islamic banking and because of their affiliation with a traditional bank. However, in the case customers interviewed, they all responded that Islamic banks from the point of view of customers might surpass conventional banking because of the interests they associate with traditional banks. There was one customer who was a small business owner who said that even if Islamic banks do not charge interests, the cost of their operations are passed on to their customers out of the high service fees they charge them.

Another SME owner said they can never be treated or compared the same as the core of their activities differs; that is, one relies on interest charges to finance their growth, while the other assumes the role of merely just an intermediary who charges only service fees but not, interest on the loans they distribute to customers.

The comments given by those interviewed are true. The two banks operate within two extremes and with different goals. Conventional banking is a product of capitalistic economies, while Islamic banking is representative of the Islam religion. As they operate on different goals to finance growth for their business, conventional banks are more 'transactional' while Islamic banks acts as business partners of investors wherein they participate actively to mitigate or reduce the risk involved in every investment.

They can however work within one organization, such as creating an Islamic window for those who may be interested to avail of Islamic services. Islamic banks, as they are not typically designed for profit-making activities, offset the risk of at their own expense. Conventional banks do not do this. The real implication of this is the varying situations or impact during any financial crisis, where Islamic banks face the risk of folding up. Hence, it will be the conventional banking concept that would support or act as a hedge for difficult times.

\section{DISCUSSION}

Generally, however, the opportunities for Islamic Banking is high knowing that there has already been a tacit understanding on how Islamic banking works most especially in a place where the dominant religion is Islam and where its people closely adheres to the Islamic faith and beliefs.

With Islam as the core basis of its culture, Omanis strictly observe Islam beliefs and practices, but are also tolerant enough towards the other forms of Islam and all other religions. Based on Islamic tenets, religious endowments, as well as taxes, such as "awqaf" and "zakat" are collected from the public but are channeled back to charitable and religious purposes.

As Omanis become more and more aware of Islamic banking practices, Islamic banks are drawn closer to more opportunities especially if its activities are directed towards providing financial support to small and medium enterprises (SMEs) whose growth are increasing along with the Government's implementation of its development plans for the country. Islamic banks must be ready to provide support to SMEs. 
The reason for this is that the presence of SMEs and with its growing number in Oman, the economy is not getting as much from this sector in as there is still a need for the Government to promote the growth of small and medium businesses. SMEs however, have lesser capability to integrate or tie up their banking activities with Islamic banks compared with large businesses, given the fact that there still remains a degree of uncertainty on how they are perceived.

However, the way Islamic principles apply in other countries it still needs to be regulated in Oman. Oman has for many years now have liberalized trade and allowed other non-Omanis to invest in Oman. Thus, with the liberalization of trade both Omanis and non-Omanis would be more interested to avail of financing with lesser risks involved in order to promote their businesses. Similarly, it would be easier to spread Islamic banking and financing, as Islam has been the official religion of Oman.

Muslims would however be more amenable to the system brought about by Islamic banking as it agrees with their existing beliefs on the prohibiting the charging of interest and in mobilizing any funds to create more investments and new job opportunities for the unemployed. Islamic banking however, can offset the charging of interest through the service fees charged to customers. In like manner, non-Muslims are also open to the idea of setting out new alternatives for capital and investments to flourish, and are likely to welcome Islamic banking in their financial systems. The growth of Islamic banking has thus far increased with other non-Muslim countries, usually those open to other religions in their homeland. The best alternative made so far by traditional banks operating internationally is to create Islamic units to serve customers who have preference towards the use of Islamic banking products and processes.

With a wider latitude of banking choices, these creates the impression for customers that these banks are more flexible and has respect for the right of individuals to exercise their freedom of choice for the common good. With a strong religious foundation, it is difficult for Islamic banks to detach itself and its precepts from social, and moral or ethical values given their social commitment and the reason for its creation. Moreover, the degree of trust in Islamic banks becomes higher as it shares the burden of losses in proportion to the amount of investments made by investors, whereby they are measured in terms of profitable operations, where both the bank and the investor share any gains.

Islamic banks are continuously growing and have been greatly considered as viable financial entities or institutions that cover many areas across the world where there are Muslim populations. The successful growth of these banks however, yet undetermined as this paper has attempted to conduct an empirical investigation on the opportunities for Islamic banking in Oman. Although Muslim populations are usually found in less developed countries, their presence and impact cannot be, set aside especially in the Sultanate of Oman as it strictly adheres to Islam as its religion. Increase in oil prices can have positive effects on the Islamic banks as they can stimulate economic activity and enlarge the picture of progress and stability. This is especially true for countries that are rich in oil. In the case of Oman however, the predicted depletion of its resources have pushed the Government to take initiatives on diversifying economic activities and capitalizing on their other resources. As an obedient lot, Omanis have thus far, achieved economic growth and development through a more unified vision, which is strongly supported by its government. Even in the case of Malaysia, Islamic banking offered a well-economic growth in the country as they also started the first Islamic system in July 1983 (Furqani \& Mulyany, 2009).

Islamic banking is found to be capable of offering products and processes that answers the need of SMEs with their risk management framework that is distinct from what conventional banking offers. Islamic banking is also careful to provide products and services that might reduce 
the misallocation of funds, as they become partners of the business. Islamic banking transactions contain the element of sharing of losses which are backed up by the bank's assets (Hanif, 2011).

\section{LIMITATIONS OF STUDY}

The study was conducted during 2010 and it was a part of a master thesis. Therefore, results are conditional to that period of study implementation and data collection. However, several improvements in the banking sector were mentioned in the article literature. Furthermore, the study has only chosen participants in the survey who are assumed to have gained an ample understanding of the concepts behind Islamic banking. The majority of these participants were bank officers and employees that have gained understanding on how banks operate, and likely about products and processes that may or may not be appealing to customers. On the other hand, customers were also chosen randomly, which to some extent they already have gained understanding on banking activities as they have made several banking transactions with their traditional banks.

\section{RECOMMENDATION}

Perceived benefits, the mitigation of risks, and the higher service charges could serve as a barrier to the possible opportunities open for Islamic banking, and for its operations to thrive successfully in Oman. Future research to explore more on the opportunities for Islamic banking is recommended in this study based on the findings and limitations presented.

For one, this research only focused on the older adults (40-60 years old) notwithstanding or recognizing the role of the younger generation which could also be a potential avenue to gain full acceptance of Islamic banking in Oman thereby increasing the chance of success. Enjoining the youth could have further substantiated the findings of this research.

Another is the determination of behavioral factors of the population, which is lacking as the research focuses into the general perception of respondents towards Islamic banking and its concepts without a discussion of the compelling reasons behind their choices of a bank or financial institution.

This could have been incorporated within the period of time when the observation and gathering of data is made the author however feels that there should be a separate study on behaviors as the assessment is done in general to determine the opportunities for Islamic Banking in Oman.

\section{CONCLUSION}

The study aimed at investigating the perceptions of bank officers, customers and employees at the bank of Islamic banking and its applicability in the sultanate of Oman. Since the study applied both qualitative and quantitative approach to answer the questions, results indicated that there is a preparedness and sincerity on the part of members to support Islamic banking within their own level of understanding of its concepts. My findings indicate that experienced and older candidates support the need for young people to run the banking systems. On the opposite there are those who still are not ready to fully go for Sharia compliant financial institutions and mix them with their corporate activities.

\section{AUTHOR CONTRIBUTIONS}

Conceptualization: Sultan Khamis Said Al Bulushi

Data Curation: Sultan Khamis Said Al Bulushi

Formal Analysis: Sultan Khamis Said Al Bulushi 
Funding Acquisition: Sultan Khamis Said Al Bulushi

Investigation: Sultan Khamis Said Al Bulushi

Methodology: Sultan Khamis Said Al Bulushi

Project Administration: Sultan Khamis Said Al Bulushi

Resources: Sultan Khamis Said Al Bulushi

Software: Sultan Khamis Said Al Bulushi

Supervision: Sultan Khamis Said Al Bulushi

Validation: Sultan Khamis Said Al Bulushi

Visualization: Sultan Khamis Said Al Bulushi

Writing - Original Draft: Sultan Khamis Said Al Bulushi

Writing - Review \& Editing: Sultan Khamis Said Al Bulushi

CONFLICT OF INTEREST STATEMENT

The author declares that there are no conflicts of interests regarding the publication of this paper.

\section{REFERENCES}

Al Bahar, A. A. (1999). "Islamic Finance and Investment: A New Era" Proceedings of the Second Harvard University Forum on Islamic Finance. Harvard University, 179-181, Center for Middle Eastern.

Al Baraka Banking Group. (2013). Islamic Banking. Retrieved from http://www.albaraka.com/default.asp?action=article $\&$ id $=46$

Al-Jarhi, A., \& Iqbal, M. (2001). Islamic Banking: Answers to Some Frequently Asked Questions, Occasional paper No. 4 Islamic Islamic Development Bank, s.l.: Islamic Research and Training Institute. .

AMEInfo.com ( 2012). Fitch sees new Islamic banks in Oman to struggle, initially. Retrieved from http://www.ameinfo.com/fitch-islamic-banks-oman-struggle-initially-314145

Belwal, R., \& Al Maqbali, A. (2019). A study of customers' perception of Islamic banking in Oman. Journal of Islamic Marketing.

Dewi, M. K., \& Ferdian, I. R. (2009) . Islamic Finance: A Therapy for Healing the Global Financial Crisis. Challenges of Globalising Financial System. Amman, Jordan: The Hashemite University.

Furqani, H., \& Mulyany, R. (2009). Islamic banking and economic growth: Empirical evidence from Malaysia. Journal of Economic Cooperation \& Development, 30(2), 59-74.

Hanif, M. (2011). Differences and Similarities in Islamic and Conventional Banking. International Journal of Business and Social Science, 2(2), 166-175.

Hasan, M., \& Dridi, J. (2010). The Effects of the Global Crisis on Islamic an Conventional Banks: A Comparative Study IMF Working Paper., s.1.: IMF. 
Kahf, M., Amad, A., \& Homud, S. (1998). Islamic Banking and Development An alternative Banking Concept?. Retrieved from http://monzer.kahf.com/papers/english/Isbnk_and_dev_alternative_banking_concept.pdf

Kpodar, M. K., \& Imam, P. A. (2010). Islamic banking: how has it diffused?. International Monetary Fund.

Lewis, M., \& Algaoud, L. (2001). Islamic Banking. Cheltenham, UK: Edward Elgar.

Loghod, H. A. (2010). Do Islamic Banks Perform Better than Conventional Banks? Evidence from Gulf Cooperation Council countries. Retrieved from www.arab-api.org.

Magd, H. A., \& McCoy, M. P. (2014). Islamic finance development in the sultanate of Oman: Barriers and recommendations. Procedia Economics and Finance, 15, 1619-1631.

Miles, M., \& Huberman, A. (1994). Qualitative Data Analysis. 2nd ed. Thousand Oaks. CA: Sage.

Mubeen, S. A., Kulkarni, N. A., \& Al Hussaini, Y. K. (2014). The future of Islamic banking in Sultanate of Oman. International Journal of Economics and Finance, 6(5), 203-209.

Muscat Daily Staff Writer (2013). OMAN SHOULD RESTRAIN SPENDING, INCREASE NONOIL REVENUES: IMF. Retrieved from http://www.muscatdaily.com/Archive/Business/Oman-should-restrain-spendingincrease-non-oil-revenues-IMF-2bws

Rettab, B., Kashani, H., Obay, L., \& Rao, A. (2010). Impact of Market Power and Efficiency on Performance of Banks in the Gulf Cooperation Council Countries. International Research Journal of Finance and Economics, 50, 190-199.

Rizwan, R. (2021). Performance Comparison of Islamic Banks and Conventional Banks in Pakistan. International Journal of Islamic Banking and Finance Research, 5(1), 34-41.

Rosmanidar, E., Al Hadi, A. A., \& Ahsan, M. (2021). Islamic Banking Performance Measurement: A Conceptual Review of Two Decades. International Journal of Islamic Banking and Finance Research, 5(1), 16-33.

Salim, B. F., \& Al Ani, M. K. (2015). The Impact of Islamic Banking Challenges and Opportunities on the Market Share: Evidence from Oman. European Journal of Economics, Finance and Administrative Sciences, (76).

Shafique, A., Faheem, M. A., \& Abdullah, I. ( 2012). Impact of Global Financial Crises on the Islamic Banking System Analysis of Islamic Financial System during Financial Crunch 2008. Arabian Journal of Business and Management Review (OMAN Chapter), 1(9), 124134. 
Siddiqi, M. (2004). Riba, Bank interest and the rationale of its prohibition, Jeddah: Islamic Research \& Training Institute Jeddah.

Siddiqui, M. (1987). Partnership And Profit-Sharing In Islamic Law. Leicester,UK: The Islamic Foundation.

Usmani, M. (2002). Meezanbank’s Guide To Islamic Banking. Karachi, Pakistan: Darul-Ishaat.

\section{Copyrights}

Copyright for this article is retained by the author(s), with first publication rights granted to the journal. This is an open-access article distributed under the terms and conditions of the Creative Commons Attribution license (https://creativecommons.org/licenses/by/4.0). 